\title{
Pengembangan Media Pembelajaran Fisika Berbasis Web Menggunakan Pendekatan Guided Discovery Learning
}

\author{
Sherly Kalatting ${ }^{1, a)}$, Vina Serevina ${ }^{2}$, I Made Astra ${ }^{2}$ \\ ${ }^{1}$ Program Studi Magister Pendidikan Fisika, Universitas Negeri Jakarta, Jakarta 13220 \\ ${ }^{2}$ Program Studi Pendidikan Fisika, Fakultas MIPA, Universitas Negeri Jakarta, Jakarta 13220 \\ Email: a)sherlykalatting@gmail.com
}

\begin{abstract}
The development of physics web based approach using a guided discovery learning has done on SMAK 5 Penabur at XI science class from March until May 2015. Development of the model used is based on Borg \& Gall with comparative descriptive data. Development of this web-based physical media is expected to assist students in understanding the substance of Physics in 2013 curriculum. After passing through the planning process, judicial review by experts of material and test media by media experts, the revision, the product tested on students are welcomed. Similarly, when disseminated to teachers. Web-based learning media is considered to overcome the limitations of the learning process and can facilitate the learners in understanding physics.
\end{abstract}

Keywords: web-based, Guided Discovery Learning, development research

\begin{abstract}
Abstrak
Pengembangan media pembelajaran fisika berbasis web menggunakan pendekatan Guided Discovery learning telah dilakukan di SMAK 5 Penabur untuk kelas XI IPA pada bulan Maret sampai Mei 2015. Pengembangan yang digunakan mengacu pada model Borg \& Gall dengan data deskriptif komparatif. Pengembangan media fisika berbasis web ini diharapakan dapat membantu siswa dalam memahami substansi Fisika pada kurikulum 2013. Setelah melewati proses perencanaan, uji materi oleh ahli materi, dan uji media oleh ahli media, revisi, produk diujicobakan pada peserta didik dengan hasil baik. Begitu pula ketika disosialisasikan ke guru se-Penabur. Media pembelajaran berbasis web dinilai dapat mengatasi keterbatasan pada proses belajar mengajar dan dapat memfasilitasi peserta didik dalam memahami materi fisika.
\end{abstract}

Kata-kata kunci : Berbasis Web, Guided Discovery learning, penelitian pengembangan

\section{PENDAHULUAN}

Penggunaan media sebagai pendamping dalam proses pembelajaran semakin dibutuhkan untuk mengatasi permasalahan yang muncul karena keterbatasan waktu, tempat, dan fasilitas lainnya. Penggunaan media dapat membangun pola pikir peserta didik yang sebelumnya bersifat abstrak menjadi konkrit. Melalui pengembangan media pembelajaran online, peserta didik dapat secara terbimbing belajar mengenai konsep-konsep fisika dan dapat meningkatkan kemampuan belajar peserta didik. Berdasarkan kemajuan teknologi media di bidang pendidikan, maka proses pembelajaran harus mengikuti teknologi terkini. Untuk itu diperlukan alat bantu yang berupa media. Pengertian media menurut Sadiman (1986) adalah segala sesuatu yang dapat digunakan untuk menyalurkan pesan dari pengirim ke penerima pesan sehingga dapat merangsang pikiran, perasaan, 
perhatian, dan minat peserta didik sehingga proses belajar terjadi. Media merupakan suatu sarana yang bersifat menyalurkan pesan dan dapat merangsang pikiran, perasaan dan kemauan peserta didik, sehingga mendorong terjadinya proses belajar pada dirinya. Media memiliki kekuatan positif dan sinergi yang mempu merubah sikap dan tingkah laku peserta didik ke arah perubahan yang kreatif dan dinamis. Oleh sebab itu, peran media sangat dibutuhkan dalam pembelajaran dimana pada saat ini media bukan hanya sebagai alat bantu tetapi lebih sebagai alat penyalur pesan dari pemberi pesan (guru) ke penerima pesan (siswa). Sehingga dalam proses belajar mengajar, guru dapat memasukkan media dalam rencana pelaksanaan pembelajaran. Oleh karena itu media pembelajaran merupakan bagian integral dalam sistem pembelajaran. Media pembelajaran hendaknya dipandang sebagai sumber belajar yang digunakan dalam memecahkan masalah yang dihadapi dalam proses mengajar. Media pembelajaran dapat memperjelas penyajian pesan dan informasi sehingga dapat memperlancar proses belajar mengajar dan meningkatkan hasil belajar (Azhar Arsyad, 2011). Penggunaan media pembelajaran juga dapat mempertinggi kualitas proses belajar mengajar, yang pada akhirnya dapat meningkatkan kualitas belajar peserta didik. Salah satu bentuk pemanfaatan media saat ini adalah melalui sarana komputer berbasis web.

Staycle C. Duplichan (2009) mengembangkan media pembelajaran menggunakan web log atau blog dalam proses belajar mengajar di Lacassine High School in Lacassine, Louisiana, dengan disambut baik oleh peserta didiknya. Charles T. Cox Jr., Joni Jordan,Melanie M. Cooper, and Ron Stevens (2006) mengembangkan media berbasis web interaktif dalam untuk meningkatkan kemampuan siswa kelas 12 dalam memecahkan masalah. Dewi S Prawiradilaga, Kunto Imbar Nursetyo dan Diana Ariani (2013) mengembangkan web based learning pada jurusan kurikulum dan teknologi pendidikan Fakultas Universitas Negeri Jakarta dengan subdomain www.courses.webbali.net, menggunakan platform LCMS (Learning Content Management System) Claroline. LCMS mengandung aspek disain pembelajaran yang lebih lengkap dibandingkan dengan LMS (Learning Management System).

Pendekatan Ilmiah terdiri dari problem-based Learning (pembelajaran berbasis masalah), project-base Learning (pembelajaran berbasis proyek) dan Discovery Learning. Proses problem-based learning, peserta didik dihadapkan pada skenario permasalahan riil; mengidentifikasi dan menganalisis permasalahan itu berdasarkan fakta- fakta dari skenario hipotesis dan memunculkan hipotesis tentang solusinya(Anita Woolfolk 2009). Project-based learning adalah pendekatan lain yang serupa dengan problem-based learning yang pada akhirnya memunculkan produksi artefak(Anita Woolfolk 2009). Metode Discovery Learning (kurikulum 2013) adalah teori belajar yang didefinisikan sebagai proses pembelajaran yang terjadi bila pelajar tidak disajikan dengan pelajaran dalam bentuk finalnya, tetapi diharapkan siswa mengorganisasi sendiri. Pada penelitian ini pendekatan yang dipakai adalah Guided Discovery Learning.

Berdasarkan pemaparan di atas, pada penelitian ini akan dikembangkan media pembelajaran Fisika berbasis Web sebagai upaya untuk meningkatkan dan mendukung pembelajaran fisika. Penulis berniat menyediakan, mengembangkan, dan mengujicobakan web sebagai salah satu media pembelajaran fisika di kelas XI IPA pada materi Karakteristik Gelombang, dengan pendekatan guided discovery learning.

\section{METODE PENELITIAN}

Metode Penelitian yang digunakan adalah penelitian pengembangan dengan model Borg and Gall (1983), educational research and development is a process used to develop and validate educational product. Dapat diartikan bahwa penelitian pengembangan pendidikan adalah sebuah proses yang digunakan untuk mengembangkan dan memvalidasi produk pendidikan. Metode penelitian dasar (basic research) akan digunakan untuk menguji produk, setelah produk teruji maka dapat diaplikasikan. Data disajikan dalam bentuk data deskriptif komparatif.

Tahapan penelitian yang dikembangkan oleh Borg \& Gall dapat dijelaskan sebagai berikut:

1. Penelitian dan pengumpulan informasi yang mencakup kajian pustaka, pengamatan, membuat kerangka kerja peneliti.

2. Perencana mencakup pendefisian ketrampilan, perumusan tujuan penelitian, menentukan prosedur kerja peneliti, penentuan urutan pembelajaran, dan uji coba skala kecil.

3. Pengembangan bentuk produk awal yang mencakup penyiapan materi pembelajaran (perancangan draf awal produk). 
4. Melakukan uji coba lapangan awal (preliminary field testing), yaitu mencobakan draf produk ke wilayah dan subjek terbatas yang dilakukan pada lima subjek yang diambil secara random. Pengumpulan data dengan wawancara, pengamatan, kuesioner dan dianalisis.

5. Revisi produk awal dilakukan sesuai dengan saran-saran pada uji coba lapangan awal.

6. Melakukan uji coba lapangan utama yaitu uji coba terhadap produk hasil revisi ke wilayah dan subjek yang lebih luas.

7. Revisi produk operasional sesuai dengan yang disarankan pada hasil uji coba lapangan utama.

8. Melakukan uji coba lapangan operasional yang dilakukan pada subjek yang lebih luas. Pengumpulan data dengan wawancara, pengamatan, dan kuesioner, dan dianalisis

9. Revisi produk akhir (revisi produk yang efektif) sesuai yang disarankan pada uji coba lapangan operasional.

10. Desiminasi dan implementasi dengan membuat laporan mengenai produk dalam bentuk kerjasama media atau link.

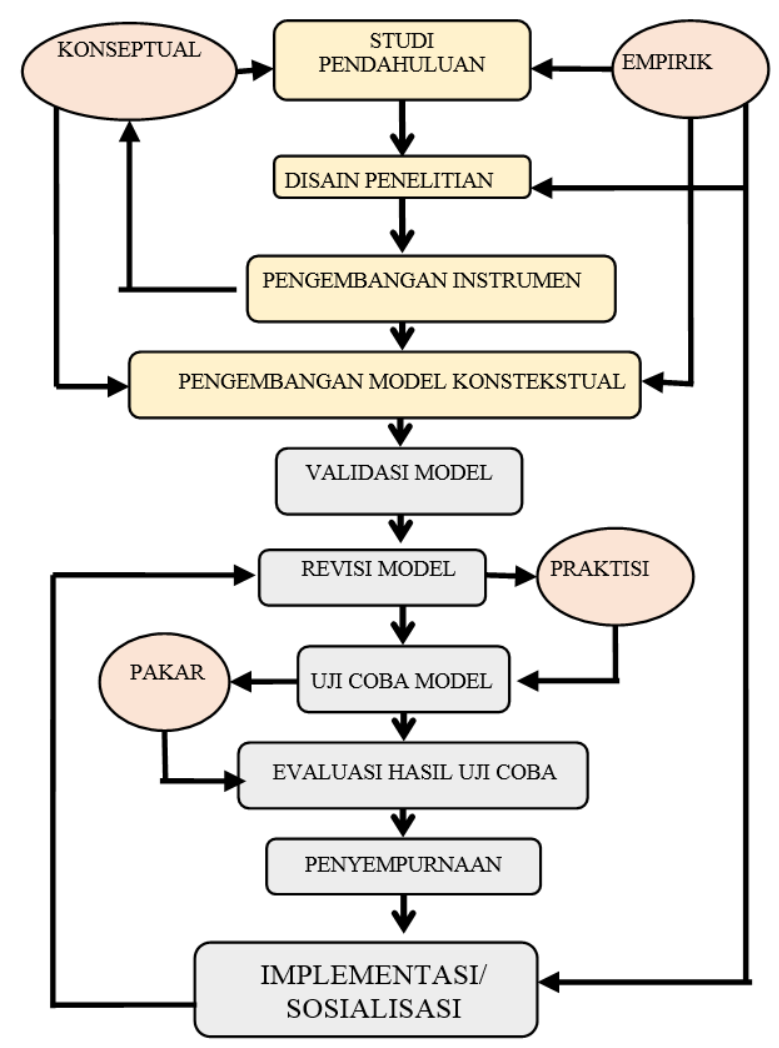

GAMBAR 1. Langkah- langkah penelitian model Borg \& Gall.

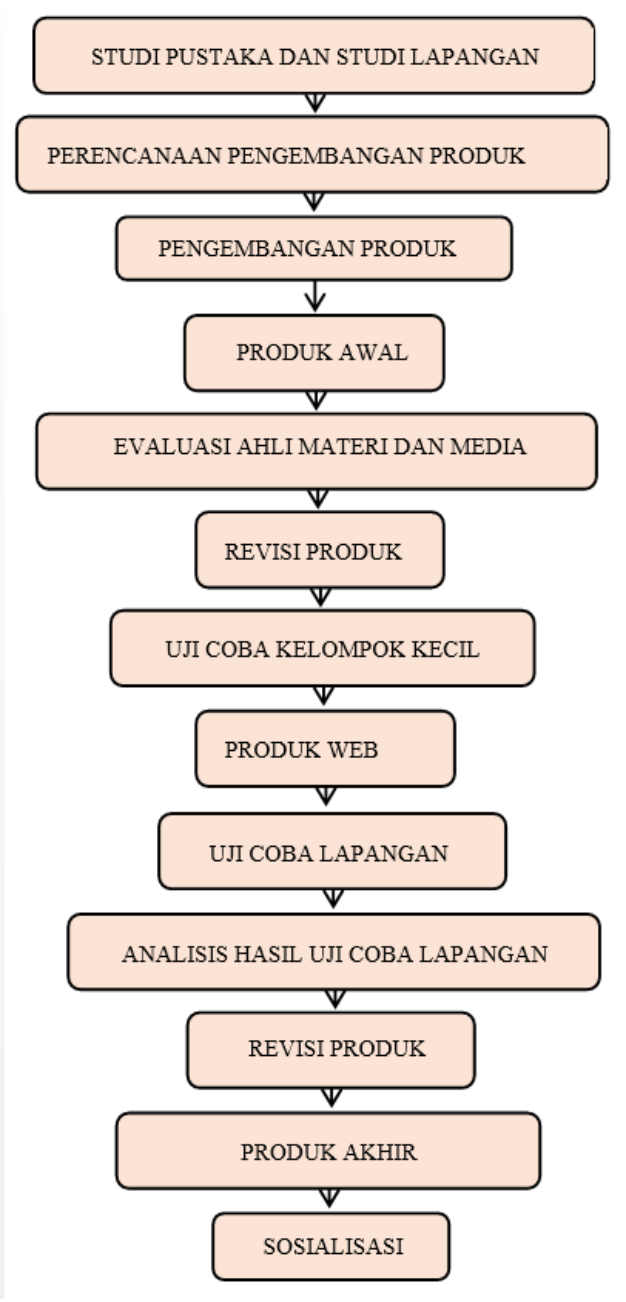

GAMBAR 2. Langkah- langkah pengembangan.

\section{HASIL DAN PEMBAHASAN}

Prosedur pengembangan media pembelajaran dapat dilihat dalam GAMBAR 2, adapun penjelasannya sebagai berikut:

1. Studi Pustaka dan Studi lapangan. Langkah awal pengembangan dilakukan identifikasi kebutuhan pembelajaran dengan tujuan mengumpulkan berbagai informasi yang relevan dengan pengembangan media pembelajaran fisika berbasis web. Identifikasi kebutuhan ini dilakukan 
dengan studi pustakan dan studi lapangan. Pada tahap perencanaan studi pustaka dilakukan dengan mengumpulkan sumber, termasuk membaca sumber-sumber terkait dengan media pembelajaran fisika, pembelajaran berbantuan internet terkait dengan penelitian pengembangan ini. Adapun studi lapangan dilakukan untuk melihat keadaan di sekolah secara langsung dengan wawancara dan kuesioner terhadap pihak- pihak terkait, yaitu peserta didik dan guru di SMAK 5 Penabur. Data yang diperoleh adalah 99,9 persen siswa SMAK 5 telah difasilitasi internet dan membutuhkan media pembelajaran fisika berbasis web.

2. Perencanaan Pengembangan Produk. Langkah kedua yang dilakukan adalah penulisan standar kurikulum dan pengembangan kurikulum yang bersifat formal maupun non formal.Media pembelajaran fisika berbasis web dibatasi pada materi Karakteristik Gelombang yang dipelajari oleh peserta didik kelas XI tingkat menengah atas.

3. Pengembangan produk. Tahap selanjutnya adalah pengembangan produk media web untuk pembelajaran fisika. Pada tahap ini, pengembang melakukan langkah-langkah antara lain: membuat storyboard, membuat alur pengembangan (flowchart), pengumpulan bahan pendukung, membuat desain, memproduksi, dan menampilkan bahan terkait untuk melengkapi produk. Storyboard membuat gagasan pengembangan tentang materi yang disajikan. Setelah storyboard disusun, pengembang membuat diagram alur pengembangan dalam bentuk flowchart. Flowchart berisi diagram yang dapat memberikan gambar alur dari satu scane ke scane yang lain. Selanjutnya, pengembang mengumpulkan bahan-bahan untuk membuat produk, seperti: materi, animasi, audio, clip-art image, dan pendukung lainnya. Pada tahap ini pengemban memanfaatkan sumber-sumber dari buku, internet serta dokumen pendukung lainnya.

4. Produk awal. Langkah selanjutnya pengembang mendisain dan membuat produk yang merupakan hasil pertama dari pengembangan Web pembelajaran dengan menggunakan platform claroline.

5. Evaluasi ahli materi dan media. Dilakukan evaluasi hasil pertama web pengembangan media pembelajaran fisika, dalam hal ini adalah evaluasi formatif. Produk yang telah dikembangkan dievaluasi oleh dua orang ahli, yaitu ahli materi dan ahli media .Ahli materi dalam pengembangan ini adalah Dr. Esmar Budi,M.T., Dr.Mangasi Alion Marpaung,M.Si. dari UNJ dan ahli media adalah Drs.Siswoyo,M.Pd., Dr.Supriyadi,M.Pd., dosen UNJ. Validasi ini penting untuk dilakukan memberikan jaminan bahwa produk awal yang dikembangkan ini layak untuk diujicobakan. Bantuan dari ahli meliputi saran, komentar dan penilaian sangat diperlukan agar tidak banyak terjadi kesalahan sesuai dengan kebutuhan. Pada tahap ini ahli materi memberikan penilaian, komentar dan saran terhadap produk dari aspek isi. Dari penilaian ahli materi, media ini perlu direvisi, seperti penambahan contoh-contoh, perbaikan istilah fisika, perbaikan urutan penyajian dan penulisan istilah fisika. Ahli media memberikan penilaian, komentar dan saran terhadap produk ini dari aspek tampilan dan pemograman. Ahli media memberikan saran perbaikan halaman utama, tampilan secara keseluruhan, kemenarikan web, kemudahan akses dan memperjelas tahapan guided discovery learning. Ahli media juga menyarankan untuk memiliki rencana antisipasi apabila pada uji coba lapangan jaringan internet di sekolah tidak mendukung. Pada akhirnya kedua ahli menyatakan layak untuk diujicobakan ke lapangan, maka penelitian melakukan uji coba produk.

6. Revisi produk Web pembelajaran Awal. Selanjutnya, dilakukan perbaikan dari kekurangan dan kelemahan pada produk web pembelajaran awal yang merupakan hasil evaluasi atau analisis awal dari ahli media dan ahli materi.

7. Uji coba kelompok kecil. Tahap ini adalah tahap uji coba dengan 5 orang terdiri dari peserta didik kls XI ipa. Tujuan dari uji coba kelompok kecil untuk mendapatkan informasi yang digunakan sebagai bahan penyempurnaan produk. Masukan yang didapatkan adalah web perlu dibuat latihan soal lebih banyak.

8. Produk Web pembelajaran utama. Setelah disetujui oleh ahli media dan ahli materi, web media pembelajaran fisika diuji cobakan di lapangan untuk mengukur dan memvalidasi web pembelajaran supaya dapat memberikan informasi tentang kekurangan dan kelemahannya.

9. Uji coba lapangan. Tahap ini merupakan usaha untuk memvalidasi web media pembelajaran fiska. Uji coba ini akan memberikan informasi tentang kekurangan dan kelemahan yang dimiliki 
serta apa saja yang harus diperbaiki da direvisi pada web media pembelajaran fisika. Web media pembelajaran fisika akan diujicobakan kepada 30 peserta didik di SMAK5 Penabur, yang menjadi sasaran akan dipilih secara acak. Pada tahap uji coba ini pengembang membagikan kuisoner dan meminta peserta didik mengisinya dengan memberi tanda cek $(\sqrt{ })$ pada kolom angka yang sebaris dengan pernyataan yang diberikan. Angka-angka tersebut dapat ditafsirkan dengan pernyataan- pernyataan sebagai berikut:

- $4=76-100 \%$ kriteria telah terpenuhi

- $3=50-75 \%$ kriteria telah terpenuhi

- $2=25-49 \%$ kriteria telah terpenuhi

- 1 = kriteria yang terpenuhi kurang dari $25 \%$

Setelah kuisioner diisi pengembang menganalisis data- data yang terkumpul dengan hasil seperti pada TABEL 1 berikut:

TABEL 1. Hasil uji coba lapangan.

\begin{tabular}{|c|c|c|c|c|c|}
\hline \multirow{2}{*}{ No } & \multirow{2}{*}{ Indikator } & \multicolumn{4}{|c|}{ Skala Penilaian } \\
\hline & & 1 & 2 & 3 & 4 \\
\hline 1. & Kejelasan petunjuk penggunaan web & & 3 & 14 & 18 \\
\hline 2. & Kemudahan mamahami alur materi malalui penggunaan bahasa & & 2 & 17 & 16 \\
\hline 3. & Kemampuan mendorong rasa ingin tau peserta didik & & 4 & 25 & 6 \\
\hline 4. & $\begin{array}{l}\text { Kemampuan media untuk meningkatkan metakognitif peserta didik dalam } \\
\text { mempelajari Fisika }\end{array}$ & & 2 & 17 & 16 \\
\hline 5. & Kemampuan media menambah pengetahuan & & & 10 & 25 \\
\hline 6. & Kemudahan untuk membaca teks/tulisan & & 1 & 9 & 25 \\
\hline 7. & $\begin{array}{l}\text { Kompatibilitas (media pembelajaran dapat dijalankan di berbagai hardware } \\
\text { dan software yang ada) }\end{array}$ & & 1 & 13 & 21 \\
\hline 8. & Reliabilitas (Program dapat berjalan dengan baik) & & 2 & 14 & 19 \\
\hline
\end{tabular}

10. Analisis hasil uji coba lapangan. Pada tahap ini dilakukan analisis menyangkut web media pembelajaran fisika yang digunakan.

11. Revisi produk Web. Selanjutnya dilakukan perbaikan produk web media pembelajaran utama. Upaya perbaikan ini dilakukan dengan pedoman hasil analisis uji coba lapangan yang telah dievaluasi oleh ahli media dan ahli materi.

12. Produk web media pembelajaran akhir. Ini adalah produk web media pembelajaran fisika akhir yang disosialisasikan ke lapangan.

13. Sosialisasi. Memasarkan atau menyebarluaskan web media pembelajaran fisika hasil pengembangan di MGMP Guru Fisika SMA se-Penabur yang terdiri dari 11 SMA dan 30 guru, dengan memberi tanda cek $(\sqrt{ })$ pada kolom angka yang sebaris dengan pernyataan yang diberikan. Angka-angka tersebut dapat ditafsirkan dengan pernyataan-pernyataan sebagai berikut:

- $4=76-100 \%$ kriteria telah terpenuhi

- $3=50-75 \%$ kriteria telah terpenuhi

- $2=25-49 \%$ kriteria telah terpenuhi

- 1 = kriteria yang terpenuhi kurang dari $25 \%$

Setelah kuisioner diisi pengembang menganalisis data-data yang terkumpul dengan hasil sebagai berikut:

\section{A. Aspek Isi}

TABEL 2. Hasil sosialisasi dari aspek isi.

\begin{tabular}{|c|c|c|c|c|c|}
\hline \multirow{2}{*}{ No } & \multirow{2}{*}{ Indikator } & \multicolumn{4}{|c|}{ Skala Penilaian } \\
\hline & & 1 & 2 & 3 & 4 \\
\hline 1. & Kesesuaian isi web dengan Kompetensi Dasar (KD) dan tujuan pembelajaran & & & 3 & 27 \\
\hline 2. & Kebenaran konsep materi ditinjau dari aspek keilmuan & & & 3 & 27 \\
\hline 3. & Penyajian apersepsi mengingatkan peserta didik pada materi yang sebelumnya & & & 14 & 16 \\
\hline 4. & Kejelasan topik pembelajaran & & & 12 & 18 \\
\hline 5. & Keruntutan materi & & & 11 & 19 \\
\hline 6. & Cakupan materi & & & 12 & 18 \\
\hline 7. & Ketuntasan Materi & & & 16 & 14 \\
\hline
\end{tabular}




\begin{tabular}{|c|c|c|c|c|}
\hline \multirow{2}{*}{ No } & \multirow{2}{*}{ Indikator } & \multicolumn{3}{|c|}{ Skala Penilaian } \\
\hline & & 12 & 3 & 4 \\
\hline 8. & $\begin{array}{l}\text { Kesesuaian tingkat kesulitan dan keabstrakan konsep dengan perkembangan kognitif peserta } \\
\text { didik SMA kelas XI }\end{array}$ & & 17 & 13 \\
\hline 9. & Keterkaitan contoh materi dengan kondisi yang ada di lingkungan sekitar & & 16 & 14 \\
\hline 10. & Kejelasan contoh yang diberikan & & 11 & 19 \\
\hline 11. & Ketepatan materi dan contoh untuk mengembangkan kemampuan Metakognitif peserta didik & & 10 & 20 \\
\hline 12. & Kesesuaian evaluasi dengan materi dan tujuan pembelajaran & & 8 & 22 \\
\hline 13. & Kebenaran kunci jawaban yang disajikan & & 4 & 26 \\
\hline 14. & Pendekatan Guided Discovery Learning pada materi yang disampaikan & & 12 & 18 \\
\hline
\end{tabular}

\section{B. Aspek Kebahasaan}

TABEL 3. Hasil sosialisasi dari aspek kebahasaan.

\begin{tabular}{|c|c|c|c|c|c|}
\hline \multirow{2}{*}{ No } & \multirow{2}{*}{ Indikator } & \multicolumn{4}{|c|}{ Skala Penilaian } \\
\hline & & 1 & 2 & 3 & 4 \\
\hline & Kejelasan petunjuk penggunaan web & & & 13 & 17 \\
\hline 2. & Kesesuaian bahasa dengan tingkat berpikir peserta didik & & & 11 & 19 \\
\hline 3. & Kesesuaian bahasa dengan tingkat pengembangan sosial emosional siswa & & & 17 & 13 \\
\hline 4. & Kemudahan mamahami alur materi malalui penggunaan bahasa & & & 10 & 20 \\
\hline 5. & Ketepatan istilah yang digunakan & & & 10 & 20 \\
\hline 6. & Kemampuan mendorong rasa ingin tau peserta didik & & & 16 & 14 \\
\hline 7. & Kesantunan penggunaan bahasa & & & 5 & 25 \\
\hline
\end{tabular}

\section{Aspek Penyajian}

TABEL 4. Hasil sosialisasi dari aspek penyajian.

\begin{tabular}{clcccc}
\hline \multirow{2}{*}{ No } & \multirow{2}{*}{ Indikator } & \multicolumn{3}{c}{ Skala Penilaian } \\
& & $\mathbf{1}$ & $\mathbf{2}$ & $\mathbf{3}$ & $\mathbf{4}$ \\
\hline 1. & Keruntutan penyajian Web & 9 & 21 \\
2. & Dukungan cara penyajian web terhadap keterlibatan peserta didik dalam pembelajaran. & 1 & 7 & 22 \\
3. & Penyajian gambar menarik dan proporsional & 2 & 11 & 16 \\
\hline
\end{tabular}

\section{Tampilan menyeluruh}

TABEL 5. Hasil sosialisasi dari tampilan menyeluruh.

\begin{tabular}{llcccc}
\multirow{2}{*}{ No } & \multirow{2}{*}{ Indikator } & \multicolumn{3}{c}{ Skala Penilaian } \\
& & $\mathbf{1}$ & $\mathbf{2}$ & $\mathbf{3}$ & $\mathbf{4}$ \\
\hline 1. & Kemenarikan Home Page & & 3 & 15 & 12 \\
2. & Kemudahan untuk membaca teks/tulisan & 1 & 11 & 18 \\
\hline
\end{tabular}

\section{E. Efek bagi Strategi Pembelajaran}

TABEL 6. Hasil sosialisasi dari efek bagi strategi pembelajaran.

\begin{tabular}{|c|c|c|c|c|}
\hline \multirow{2}{*}{ No } & \multirow{2}{*}{ Indikator } & \multicolumn{3}{|c|}{ Skala Penilaian } \\
\hline & & 12 & 3 & 4 \\
\hline 1. & Kemudahan penggunaan & & 12 & 18 \\
\hline 2. & Dukungan media bagi pendekatan Guided Discovery Learning & & 15 & 15 \\
\hline 3. & $\begin{array}{l}\text { Kemampuan media untuk meningkatkan metakognitif peserta didik dalam } \\
\text { mempelajari Fisika }\end{array}$ & & 13 & 17 \\
\hline 4. & Kemampuan media menambah pengetahuan & & 11 & 19 \\
\hline
\end{tabular}

\section{E. Aspek Rekayasa Perangkat Lunak}

TABEL 7. Hasil sosialisasi dari aspek rekayasa perangkat lunak.

\begin{tabular}{clrcc}
\hline \multirow{2}{*}{ No } & \multicolumn{1}{c}{ Indikator } & \multicolumn{3}{c}{ Skala Penilaian } \\
& \multicolumn{1}{|c}{} & $\mathbf{2}$ & $\mathbf{3}$ & $\mathbf{4}$ \\
\hline 1. & Kompatibilitas (media pembelajaran dapat dijalankan di berbagai & & 16 & 14 \\
& hardware dan software yang ada) & & \\
2. & Reliabilitas (Program dapat berjalan dengan baik) & 15 & 15 \\
3. & Usabilitas (mudah digunakan dan sederhana dalam pengoperasiannya) & 10 & 20 \\
4. & Maintainable (dapat dikelola dengan mudah) & 12 & 18 \\
\hline
\end{tabular}

Setelah dilakukan prosedur pengembangan maka dihasilkan media pembelajaran berbasis web dengan alamat www.sherlyfisika.com, dengan tampilan homepage sebagai berikut: 


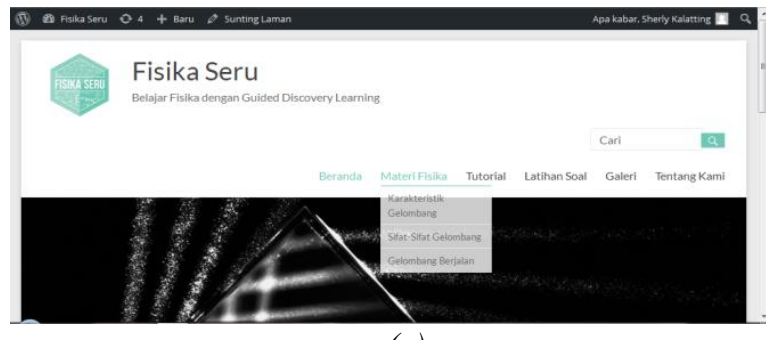

(a)

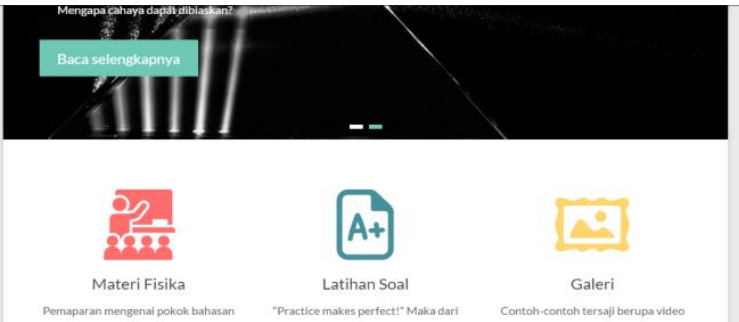

(b)

GAMBAR 3. (a) Halaman depan web bagian atas (b) Halaman depan web bagian bawah

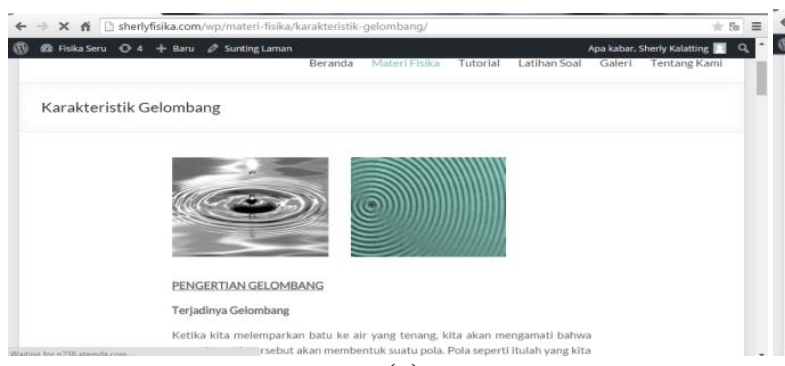

(a)

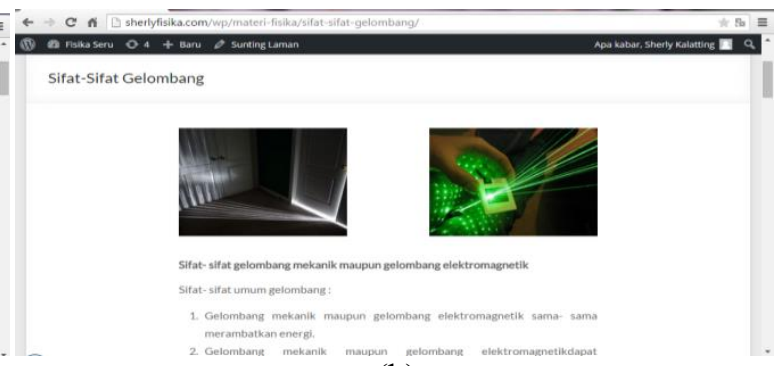

(b)

GAMBAR 4. (a) Tampilan dalam menu karakteristik gelombang (b) Tampilan menu tutorial

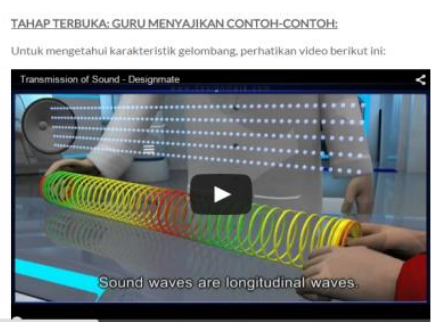

(a)

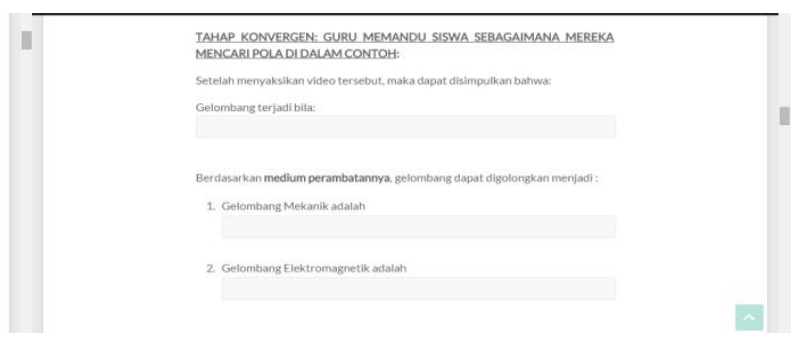

(b)

GAMBAR 5. (a) Tahap terbuka dan (b) Tahapan konvergen dalam Guided Discovery Learning

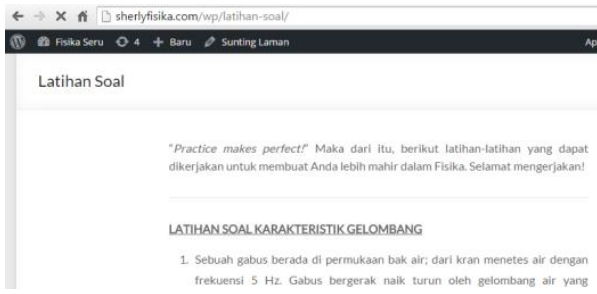

(a)

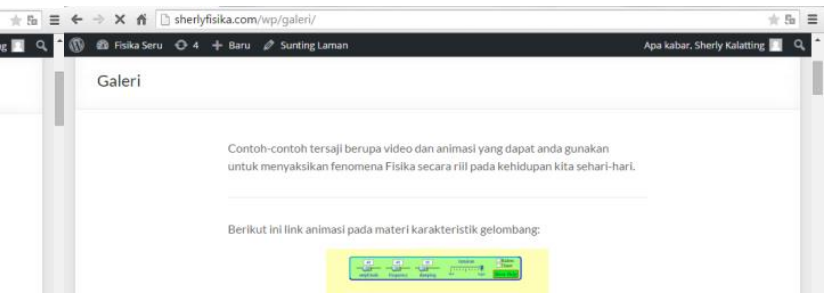

(b)

GAMBAR 6. (a) Menu Latihan soal (b) Menu Galeri

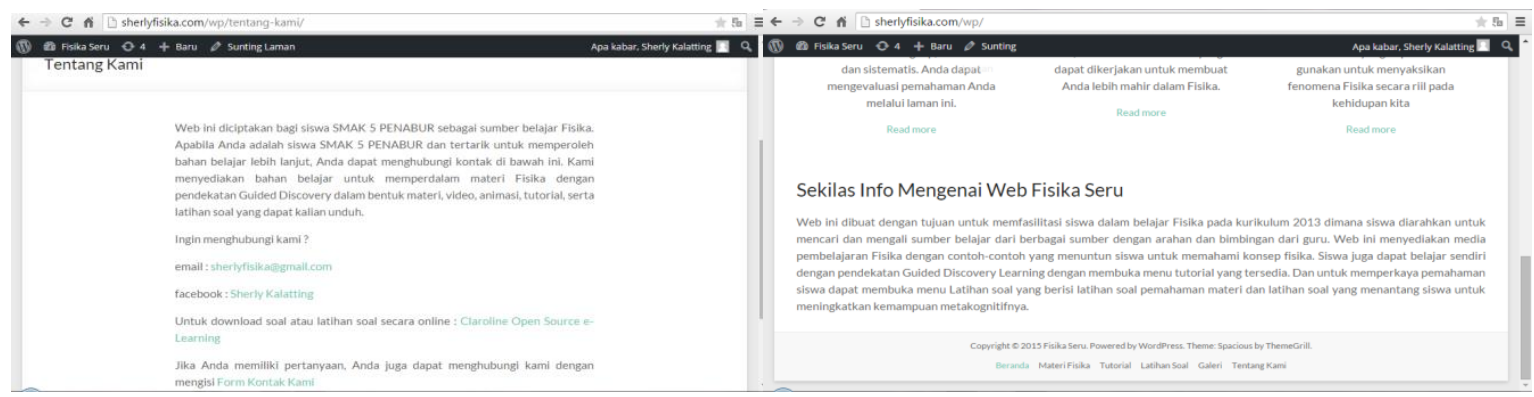

(a)

(b)

GAMBAR 7. (a) Menu Tentang kami (b) Sekilas info mengenai Web Fisika Seru 


\section{KESIMPULAN}

Setelah melewati tahapan penelitian pengembangan, maka dapat disimpulkan bahwa media pembelajaran berbasis web dengan pendekatan Guided Discovery Learning diperlukan untuk memfasilitasi dan membantu Peserta didik dalam belajar Fisika. Guru-guru Fisika se-Penabur Jakarta juga menyambut baik media berbasis web ini.

\section{UCAPAN TERIMAKASIH}

Terima kasih kepada Kepala SMAK 5 Penabur yang memberikan kesempatan dan sumbang saran bagi peneliti dalam mengembangkan media ini. Terima kasih kepada Siswa XII KBI angkatan XX yang menyediakan waktu, pikiran dan tenaganya dalam menyempurnakan media ini. Terima kasih kepada Dr. Esmar Budi, M.T., Dr. Mangasi Alion Marpaung, M.Si., Drs. Siswoyo, M.Pd., Dr. Supriyadi, M.Pd. yang telah memberikan saran perbaikan sebagai ahli materi dan ahli media. Terima kasih juga kepada seluruh guru Fisika se-penabur Jakarta yang telah memberikan saran yang membangun.

\section{REFERENSI}

Anita Woolfolk, Educational Psychology Active Learning Edition, Edisi kesepuluh, bagian kedua, Pustaka Pelajar, (2009), p 159-160.

Azhar Arsyad, Media Pembelajaran, Jakarta: RajaGrafindo Persada (2011), p23.

Borg \& Gall, 1983, Education Research: An Introduction (New York: Longman,1983) 624, p775.

Charles T. Cox Jr., Joni Jordan,Melanie M. Cooper, and Ron Stevens,2006, Assessing Student Understanding withTechnology A website uses authentic scenarios to gauge students'problemsolving skills and science knowledge, The Scince Teacher mei/june 2006, p56-60.

Dewi Salma Prawiradilaga, Mozaik Teknologi Pendidikan: E-Learning, Edisi pertama, Kencana Prenadamedia Group,(2013), p282.

Sadiman, A.S., Raharjo, R., Haryono, A., dan Rahardjito, Media Pendidikan: Pengertian, Pengembangan, dan Pemanfaatannya. Jakarta PT RajaGrafindo Persada (1986), p3.

Staycle C. Duplichan, Using Web Logs in the Science Classroom, Science Scope, National Science Teachers Association(2009), pp 33-37. 